Alenka Kocbek

UDK 81'25:34

Pedagoška fakulteta, Univerza na Primorskem

alenka.kocbek@pef.upr.si
DOI: 10.4312/vestnik.9.107-124

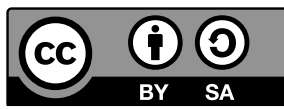

\title{
DESET SMERNIC ZA PREVAJANJE PRAVNIH BESEDIL
}

\section{1}

\section{UVOD}

Prevodoslovni model, ki je predstavljen v tem prispevku, je bil zasnovan za prevajanje pravnih besedil z namenom upoštevati in zajeti vse znotrajbesedilne in zunajbesedilne razsežnosti pravnih besedil kot specifičnih besedilnih vrst. Tako so pravna besedila preučevana najprej v luči besediloslovnih in prevodoslovnih dognanj. S stališča besediloslovja se pravna besedila izkažejo kot razmeroma konvencionalna besedila, ki se uvrščajo v eno od kategorij pravnih besedilnih vrst po Busseju (2000). Ker jih vselej zaznamuje pravna kultura, v kateri nastajajo, predstavljajo uveljavljeni način ubesediljenja pravnih razmerij v neki kulturi in jih je kot take mogoče pojmovati kot kultureme - vzorce sporazumevalnega obnašanja (Oksaar 1988). Pojem kulturema smiselno povezuje besediloslovni pogled na pravna besedila s prevodoslovjem, saj ta pojem v nekoliko spremenjeni obliki, t.j. kot formaliziran, družbeno in pravno vpet pojav, ki v določeni pojavni obliki in z določeno funkcijo obstaja samo v eni od primerjanih kulture (Vermeer 1983, Nord 1997), prevzemajo tudi funkcionalistični prevodoslovni pristopi. Funkcionalistični pogledi, ki izpostavljajo funkcijo ciljnega besedila, predvsem teorija skoposa (Reißova in Vermeer 1984), se izkažejo kot primeren teoretski okvir za prevode pravnih besedil, saj je zanje značilna jasno izražena funkcija, skopos pa ima tudi odločilno vlogo pri izbiri vrste prevoda in ustrezne prevajalske strategije. Pojmovanje besedila kot kulturema se v glavnih potezah ujema tudi s teorijo memov (Chesterman 1997), v skladu s katero je ustaljene besedilne vrste, ki so se razvile v določenih kulturnih okoljih in ki se prek prevodov prenašajo v druga okolja, pri čemer doživljajo spremembe in prilagoditve, hkrati pa tudi vplivajo na ciljne kulture, mogoče pojmovati kot ubesediljene kulturne prakse, torej kompleksne meme. Da bi izhodiščno besedilo v skladu z vsakokratnim skoposom prek prevoda čimbolj ustrezno prenesli v ciljno kulturo, je potrebno najprej natančno določiti kulturema ustrezne besedilne vrste $\mathrm{v}$ izhodiščni in ciljni kulturi. $\mathrm{V}$ ta namen je smiselno kulturem besedila razčleniti in ločeno obravnavati njegove zunajbesedilne in znotrajbesedilne razsežnosti.

Na zunajbesedilni ravni je pravno besedilo vpeto v pravno kulturo, v kateri nastaja in v kateri se uporablja. Na tej ravni se vpliv kulture kaže predvsem kot vpliv ustreznega pravnega reda, ki posredno ali neposredno predpisuje vsebino besedila in s tem njegovo 
makrostrukturo z vsebinskimi elementi. Na mikrostrukturni ravni se kulturna vpetost besedila kaže skozi vpliv vsakokratnega pravnega jezika na leksikalni, skladenjski, slogovni in pragmatični ravni. Različne pravne kulture na posameznih ravneh besedila uporabljajo ustaljene formulacije, ki jih je razumeti kot kulturne prakse (meme), ki so se v različnih zgodovinskih obdobjih uveljavile $\mathrm{v}$ določenem kulturnem okolju in ki se pri tvorbi sorodnih besedilnih vrst posnemajo, prenašajo, pa tudi prilagajajo in spreminjajo. To pojmovanje povsem ustreza pojmovanju memov, ki tako na različnih ravneh besedila oblikujejo njegovo memetsko strukturo (Kocbek 2011, 168 - 169).

Pravna besedila so odločilno vpeta $\mathrm{v}$ pripadajočo pravno kulturo in oblikovana $\mathrm{v}$ pravnih jezikih, ki so sistemsko vezani na vsakokratni pravni red, zato mora prevajalski model, ki je namenjen prevajanju pravnih besedil, združiti prevodoslovna načela $\mathrm{s}$ temelji primerjalnega prava in pravnega jezikoslovja $\mathrm{v}$ interdisciplinaren pristop, ki sledi holističnemu prevajalskemu pristopu Snell-Hornbyjeve (1995) in se navezuje na dela avtorjev, ki se ukvarjajo izključno s problematiko prevajanja pravnih besedil, kot so Caova (2007), de Groot (1992) in Sandrini (1999) ter pravnega jezikoslovja (Mattila 2006). Interdisciplinarni značaj pravnega prevajanja zahteva od prevajalca tudi poznavanje primerjalnega prava, kar zadeva razlike med pravnimi družinami in njihove učinke na pravne jezike in posledično na prevedljivost pravnih besedil.

Teoretske smernice so podprte $\mathrm{z}$ ugotovitvami protistavne analize pogodbenih besedil v slovenskem, nemškem in angleškem jeziku, v okviru katere je bila preučevana njihova memetska struktura. Izsledki te analize so omogočili prepoznavanje prevladujočih kulturemov, ki so se uveljavili v nemški, anglo-ameriški in slovenski pravni kulturi. S primerjavo teh kulturemov so bile prepoznane univerzalne značilnosti in pa tiste, ki so specifične ali prototipične za določeno pravno kulturo, kot tudi nabor jezikovnih sredstev, s katerimi so v vsaki od teh kultur ubesediljena pravna razmerja. Študija je pokazala, da je pri prevodih, pri katerih prevajamo med jezikoma, ki sta vezana na sorodne pravne sisteme, pričakovati manj težav, saj gre $\mathrm{v}$ tem primeru za kulturne prenose sorodnih, če ne že povsem enakovrednih pojmov. Kot izjemno problematična se je izkazala raba angleškega pravnega jezika kot lingve franke, saj je kulturna podstat tega jezika anglo-ameriški pravni sistem, ta pa se bistveno razlikuje od pravih sistemov t. i. celinskoevropske pravne družine.

Pričujoči model mozaično združuje različne prevodoslovne pristope z ugotovitvami primerjalnega prava. Funkcionalistično načelo kulturne vpetosti besedil, ki se uresničuje tako v konceptu kulturema kot tudi v kulturnospecifični memetski strukturi besedil, se v pravnih besedilih udejanja na več ravneh. Vsako pravno besedilo je namreč vpeto v določen pravni sistem (nacionalni ali nadnacionalni pravni red), ki z relevantnimi zakoni in 
pravnimi pravili neposredno vpliva na njegovo vsebino in oblikuje mem na zunajbesedilni ravni. Nadalje je na besedilni ravni prototipične sestavine besedila smiselno pojmovati kot meme, ki so se oblikovali v posameznih pravnih kulturah skozi medsebojno delovanje vsakokratnega pravnega sistema in jezika in se kažejo tako na makro ravni, torej v vsebini in obsegu besedila, kot na mikro ravni - v uporabljenih jezikovnih strukturah na leksikalni, skladenjski, slogovni in pragmatični ravni. Model nas tako v smiselnem zaporedju desetih korakov vodi skozi postopek prepoznavanja nameravane uporabe ciljnega besedila (skoposa) in izbire najprimernejše vrste prevoda, določanja besedilne vrste izvirnega besedila in področja prava, kamor sodi, prek preučitve pravnih sistemov in pravnih jezikov, ki so udeleženi v prevodu, ter določanja stopnje njihove sorodnosti, do določanja najprej kulturema izvirnega besedila, nato pa hipotetičnega kulturema enake ali sorodne besedilne vrste v ciljni kulturi in oblikovanja ciljnega besedila kot mozaične strukture, v kateri so zastopani tako memi ciljne kot tudi izvirne kulture, izbrani glede na ugotovljeni skopos. Zaključna faza je namenjena preverjanju oz. zagotavljanju pravne varnosti ciljnega besedila.

\subsection{Določanje skoposa in ustrezne vrste prevoda}

$\mathrm{V}$ tej fazi prevajalec uporabi podatke, vsebovane $\mathrm{v}$ naročilu prevoda, pridobi potrebne dodatne informacije od naročnika prevoda in po potrebi ovrednoti okoliščine sporazumevalne situacije, za katero je potreben prevod, ter na ta način določi skopos, torej predvideno uporabo ciljnega besedila. Pri prevodih pravnih besedil je možen širok razpon skoposov, ki sega od prevoda, ki bo služil zgolj kot informacija o izvirnem besedilu za prejemnika v ciljni kulturi, ki ne obvlada izvirnega jezika, do prevoda besedila, ki bo imel status izvirnika, torej avtentičnega besedila v ciljni kulturi.

Potem ko bo določil skopos, bo prevajalec moral izbrati vrsto prevoda, ki ga bo treba izdelati glede na načrtovani skopos. Caova v svoji kategorizacija upošteva vso specifičnost prevajanja $\mathrm{v}$ pravnem okolju in predvideva tri kategorije pravnih prevodov: normativne, informativne in prevode v splošne pravne ali sodne namene (2007, 10-12).

Prevodi v normativne namene so prevodi mednarodnih pravnih instrumentov v dvoali večjezičnih pravosodnih sistemih, kjer sta izvirno in ciljno besedilo enako pravno obvezujoča. Ta vrsta prevoda je potrebna, ko gre za prevode pravnih besedil, ki nastajajo npr. na dvojezičnih območjih Republike Slovenije, v Švici ali pa kot ena od različic večjezičnih besedil, npr. pogodb, ki se sklepajo znotraj nadnacionalnih pravnih ureditev, kakršni sta OZN ali EU, ali v okviru mednarodnih organizacij. Te vrste besedil običajno nastanejo v eni jezikovni različici, kasneje se izdela prevod, ki pa ima status originala in enako pravno moč kot izvirnik. Primeri takih prevodov so pravna besedila, prevedena v okviru dvo- ali večjezičnih pravnih ureditev (kakršna so dvojezična območja Republike Slovenije), večjezični pravni instrumenti OZN ali EU, pa tudi prevodi dokumentov, 
kakršni so pogodbe, ki so sklenjene v dveh ali več jezikovnih različicah, ki so vse pravno zavezujoče.

Informativni prevodi so prevodi, pri katerih ima ciljno besedilo zgolj informativno vrednost, ni pa pravno zavezujoče. Pri tem gre za prevode različnih zvrsti pravnih besedil (zakonov, sodnih odločb, besedil s področja pravne znanosti), ki so izdelani zato, da bi prejemnikom v ciljni kulturi v obliki dokumenta posredovali informacije o izvirniku, pri čemer pa prevod ni pravno zavezujoč in ima zgolj informativno vrednost. Ti prevodi pogosto služijo kot vir informacij o drugačni pravni ureditvi (npr. besedila iz anglo-ameriške pravne ureditve prevedena za pravne strokovnjake iz celinskoevropskih pravnih okolij v študijske namene). Ta vrsta prevodov je včasih namenjena tudi prejemnikom zunaj pravnega okolja.

Tretji možni tip prevoda glede na skopos je prevod v splošne pravne ali sodne namene, pri katerem se izvirna besedila prevajajo za uporabo v sodnem postopku kot dokumentarno dokazno gradivo. Ti prevodi imajo tako informativno kot tudi deskriptivno vrednost. Praviloma so tovrstni prevodi poverjeni sodno zapriseženim prevajalcem, ki z overitveno klavzulo potrdijo, da je prevod enakovreden izvirniku. V takšnih postopkih je včasih treba prevajati tudi dokumente, ki običajno nimajo statusa pravnega instrumenta, kot npr. poslovno ali zasebno korespondenco, izjave prič, izvedenska mnenja in različna druga dokazila in dokumente, ki jih ne sestavljajo pravni strokovnjaki in niso zapisani v pravnem jeziku, vendar vstopajo $\mathrm{v}$ sfero pravne komunikacije za potrebe sodnega postopka. Ti prevodi so namenjeni strankam v sodnem postopku, ki ne obvladajo uradnega jezika sodišča, ali pa odvetnikom in sodnim uradnikom, ki jim mora biti zagotovljeno razumevanje izvirnih dokumentov, pisanih $\mathrm{v}$ jeziku, ki ni uradni jezik sodišča.

Izkušen prevajalec bo običajno sposoben sam določiti skopos in vrsto prevoda, ki najbolj ustreza skoposu in vsakokratnemu pravnemu okolju, potrebne informacije s tem v zvezi pa so lahko vsebovane v naročilu prevoda, ki, kot opozarja teorija skoposa, lahko znatno pripomore $\mathrm{h}$ kakovosti in funkcionalnosti prevoda.

\subsection{Določanje področja prava, na katero sodi izvirno besedilo}

Po določitvi skoposa in ustrezne vrste prevoda je treba določiti področje prava, ki mu pripada izvirno besedilo (gospodarsko, civilno, kazensko pravo itd.). Pri tem nam termini, ki izražajo pojme, specifične za izvirno pravno kulturo, lahko služijo kot neke vrste kažipot. Tako bi moral prevajalec prepoznati npr. termin consideration kot enega ključnih pojmov anglo-ameriškega pogodbenega prava (Contract Law) in besedilo takoj razvrstiti kot pogodbo, sporazum ali dogovor. Podobno bi termina kot sta equitable remedies ali equitable rights morala delovati kot neke vrste kažipot, ki prevajalca usmeri na področje prava pravičnosti (equity), enega temeljnih področij anglo-ameriškega prava, termin prokurist/ 
Prokurist $\mathrm{v}$ nemškem ali slovenskem besedilu pa bo pripomogel besedilo uvrstiti na področje statusnega prava.

\subsection{Določanje besedilne vrste izvirnega besedila}

Večino pravnih terminov je mogoče popolnoma razumeti in ustrezno interpretirati šele $\mathrm{v}$ kontekstu določene pravne besedilne vrste (Sager 1990, 58-59). Besedilna vrsta določenega pravnega področja predstavlja tisti ključni kontekst, ki zaznamuje in določa končni pomen uporabljenega termina (Sager 1990, 101), kar je razvidno npr. pri angleškem terminu privity, ki ima glede na področje uporabe oz. kontekst lahko različen pomen (npr. privity of contract $\mathrm{v}$ primerjavi s privity of possession) ali nemškem glagolu kündigen (einen Vertrag/ein Arbeitsverhältnis kündigen proti jemandem kündigen).

Pravna besedila imajo običajno jasno funkcijo in tudi prevodi teh besedil še vedno služijo določenemu komunikacijskemu namenu, čeprav je ta morda drugačen od namena izvirnega besedila. Busse (2000, 4-20) je razvil tipologijo pravnih besedil, ki pravna besedila razvršča po njihovi funkciji (pri čemer se navezuje na besediloslovne pristope, predvsem na teorijo govornih dejanj) in glede na področja prava ter obsega devet razredov:

- besedilne vrste $\mathrm{z}$ normativno močjo, h katerim prišteva ustavo, zakone, odredbe, statute in podobna besedila;

- $\quad$ besedilne vrste, ki razlagajo in tolmačijo normativna besedila, kot so komentarji zakonov, izvedenska mnenja pravnih strokovnjakov ipd.;

- $\quad$ besedilne vrste sodne prakse, kot so sodbe sodišč, dispozitivi, sodni sklepi in sorodna besedila;

- $\quad$ besedilne vrste, ki so v rabi v postopkih za iskanje pravno ustrezne rešitve, kakršne so obtožnice, pisanja oz. vloge odvetnikov, sodni zapisniki (npr. zapisniki zaslišanj), predlogi, prošnje, ugovori ipd.;

- $\quad$ besedilne vrste, s katerimi se sklicujemo na pravne predpise in jih uveljavljamo, kot so različne vloge, zahtevki, predlogi, prošnje, oporoke;

- besedilne vrste za uresničevanje in izvrševanje pravnih predpisov, kot so prijava, zaporni nalog, sodna ali zunajsodna poravnava;

- besedilne vrste pogodbene narave, kot so notarska pogodba, civilnopravna pogodba, pogodba javnega prava, gospodarska pogodba, statut gospodarske družbe, pravilnik, splošni pogoji poslovanja ipd.;

- $\quad$ besedilne vrste $\mathrm{z}$ značajem uradne ali notarske listine, ki obsegajo vse vrste uradnih listin, overitev, vpise oz. registracije v zemljiško knjigo, matično knjigo, sodni register gospodarskih družb ipd. ter

- besedilne vrste pravne znanosti in pravnega izobraževanja, pri katerih gre za vse vrste pravnih učbenikov, strokovnih in znanstvenih člankov s področja prava, pravne slovarje, pravne leksikone, zbirke pravnih dokumentov in sorodna besedila. 
Ta kategorizacija se navezuje na Sagerjevo $(1997,31)$ tolmačenje, da besedilne vrste, ki sledijo uveljavljenim vzorcem (torej kulturemi), izhajajo iz ustaljenih sporazumevalnih situacij in so posebno učinkovite pri posredovanju informacij, zato ker temeljijo na družbenih in védenjskih povezavah udeležencev v komunikaciji. Sager tudi opozarja, da je za potrebe prevoda potrebno določiti besedilno vrsto izhodiščnega besedila in nato (skladno s skoposom) vzporedno besedilno vrsto v ciljni kulturi, če pa takšna besedilna vrsta v ciljni kulturi ne obstaja, ustvariti prevodno-pogojeno besedilno vrsto $(1997,39)$. Prevod tako včasih postane sredstvo vnašanja nove besedilne vrste $\mathrm{v}$ ciljno kulturo in takšne uvožene besedilne vrste se pogosto popolnoma in enakovredno vključijo v nabor besedilnih vrst ciljne kulture (tak primer predstavljajo direktive EU, ki so na tak način vstopile v pravne kulture držav članic in so zdaj ena od uveljavljenih pravnih besedilnih vrst nacionalnih pravnih kultur).

Termini, s pomočjo katerih smo določili področje prava in besedilno vrsto, praviloma opozarjajo na specifične pravne pojme, kategorije ali področja izvirnega pravnega sistema (meme), ki zaradi razlike med pravimi sistemi nimajo vselej ustreznic v ciljnem pravnem sistemu in zato zahtevajo posebno pozornost in specifične prevajalske rešitve. Da bi jih znal prepoznati, potrebuje prevajalec temeljna znanja primerjalnega prava glede razlik in sorodnosti med pravnimi družinami. Zato je v naslednji fazi potrebno preučiti in primerjati pravne sisteme, ki so udeleženi v prevodu.

\subsection{Določanje pravnih sistemov, ki sodelujejo v prevodu, in stopnje njihove sorodnosti}

V tej fazi mora prevajalec določiti pravne družine, ki jim pripadajo pravni sistemi, ki sodelujejo v prevodu, in ovrednotiti stopnjo njihove sorodnosti. Ob ustreznem poznavanju značilnosti posameznih pravnih družin in razlik med njimi, mu bo to omogočilo predvideti, na katerih področjih lahko pričakuje več težav v prevajalskem smislu. Pravne ureditve posameznih držav se med seboj razlikujejo in doslej še ni bila vzpostavljena mednarodno veljavna pravna terminologija. Vsaka država (v nekaterih primerih celo posamezne regije znotraj neke države) je razvila svojo neodvisno pravno terminologijo, večjezična pravna terminologija pa nastaja le postopoma znotraj nadnacionalnih pravnih sistemov, kakršno je pravo EU. Ta terminologija se nato uvaja v uporabo na posameznih področjih evropskega prava, na katerih poteka proces harmonizacije.

Pravni sistemi obstajajo neodvisno od pravnih jezikov, ki se v njih uporabljajo, nastanejo pa kot posledica delovanja družbenih in političnih okoliščin. Med pravnim jezikom in pravnimi sistemi ni neposredne korelacije. Neki pravni sistem lahko uporablja različne jezike (npr. Švica ali Kanada, dvojezična območja v Avstriji, Italiji, Sloveniji), prav tako pa je neko jezikovno območje lahko razdeljeno na različne pravne sisteme (Združeno kraljestvo ali ZDA). 
Zweigert in Kötz (1998) pravne sisteme združujeta v družine na podlagi njihovega zgodovinskega razvoja, specifičnega načina pravnega razmišljanja, značilnih pravnih inštitucij, pravnih virov in njihove obravnave oz. upoštevanja, kot tudi na podlagi ideoloških parametrov. Tako razlikujeta med osmimi poglavitnimi pravnimi družinami (1998, 68-72): romansko, germansko, nordijsko, anglo-ameriško (common-law), socialistično družino, pravom Daljnega Vzhoda, islamskim in hindujskim pravom.

Dve najvplivnejši pravni družini sta v današnjem času družina common-law (imenovana tudi anglo-ameriška ali anglosaška družina) in pa kontinentalno ali celinskoevropsko pravo (angl. civil law) oz. romansko-germanska družina, ki jima pripada 80 odstotkov držav vsega sveta.

Anglo-ameriška pravna družina vključuje Anglijo in Wales, ZDA, Avstralijo, Novo Zelandijo, Kanado, nekatere nekdanje angleške kolonije v Afriki in Aziji, kot so Nigerija, Kenija, Singapur, Malezija in Hong Kong, medtem ko družini kontinentalnega prava pripadajo Francija, Nemčija, Švica, Avstrija, države Latinske Amerike, Turčija, nekatere arabske države, severnoafriške države, Japonska in Južna Koreja. Nekateri pravni sistemi so hibridi, ki so nastali z mešanjem vplivov anglo-ameriškega in kontinentalnega prava, kot npr. Izrael, Južna Afrika, provinci Quebec v Kanadi, Louisiana v ZDA, Škotska, Filipini in Grčija. Caova tudi pravni sistem Evropske unije uvršča med t. i. mešane jurisdikcije $(2007,25)$.

Pravni sistemi, ki sodijo v t. i. družino kontinentalnega prava, ki vključuje romanski, germanski in nordijski pravni sistem, so relativno sorodni. Imajo skupne podlage v rimski pravni tradiciji in zanje je značilna kodifikacija, kar pomeni, da so najpomembnejša pravila in predpisi kodificirani oz. določeni v pisnih pravnih virih. Pravni sistemi drugih držav in kultur, ki temeljijo na drugačnih tradicijah, pa so težko primerljivi, kar še zlasti velja za pravo Daljnega Vzhoda, islamsko in hindujsko pravo.

Anglo-ameriška pravna družina temelji na treh osnovnih področjih: na občem pravu (common law), pravu pravičnosti (equity) in uzakonjenem pravu (statute law). Pravo te družine pogosto opisujejo tudi kot pravo, ki ga ustvarjajo sodniki (judge-made law), ker ne temelji na pisnih zakonikih, ampak na odločitvah, ki so jih sodniki sprejeli v predhodnih pravnih zadevah, torej na sodni praksi, zaradi česar ga imenujejo tudi case law. Equity (pravo pravičnosti) označuje sistem pravil, ki veljajo ob občemu pravu in nimajo ustreznice v kontinentalnem pravu. Statute law označuje uzakonjeno pravo (npr. zakone, ki jih sprejema parlament), torej tiste pravne vire, ki v anglo-ameriškem pravnem sistemu obstajajo v kodificirani oz. pisni obliki.

Sistem kontinentalnega prava izvira iz antičnega rimskega prava, kakršno je bilo kodificirano v kodeksu Corpus Juris Civilis cesarja Justinijana (528-534 n.št.), zaradi česar ga pogosto tudi imenujemo civilno pravo. Kasneje so ga od srednjega veka dalje razvijali srednjeveški pravni učenjaki. Predstavlja najstarejšo pravno tradicijo zahodnega sveta. Prvotno je kontinentalno pravo predstavljalo en sam enoten pravni sistem v večini Evrope, z nastankom nacionalnih držav v 17. stoletju in v času francoske revolucije pa se je 
ta sistem razgradil $\mathrm{v}$ ločene nacionalne pravne sisteme. Te spremembe so se še poglobile z nastankom ločenih nacionalnih zakonikov oz. kodeksov, od katerih so bili francoski Napoleonov kodeks ter nemški in švicarski zakonik najvplivnejši. Civilno pravo se je razvilo na področju celinske Evrope in se je kasneje razširilo po vsem svetu, predvsem v Latinsko Ameriko in Azijo. Nekateri avtorji trdijo, da je kontinentalno pravo služilo tudi kot temelj socialističnemu pravu.

$\mathrm{Na}$ področju pravnih institutov so značilni instituti anglo-ameriškega sistema, ki nimajo ustreznic $\mathrm{v}$ kontinentalnem pravu in so kot taki skoraj neprevedljivi, npr. specifična pravna ureditev skrbništva oz. fiduciarnih razmerij (trust law), ureditev deliktnega prava (law of torts), estoppel (s celo paleto pomenov, ki pa se najpogosteje prevaja kot prekluzija, to je izguba pravice do uveljavljanja določene pravice zaradi prejšnjih temu nasprotujočih ravnanj ali izjav). Anglo-ameriško pravo poleg tega razlikuje med kategorijami, kakršno je pogodbeno pravo (contract law) in odškodninsko pravo (law of tort) kot posebnima vejama prava, ne ločuje pa javnega in zasebnega prava na način, ki velja v kontinentalnem pravu (de Cruz 1999). Znotraj kontinentalne pravne družine v vseh državah obstajajo ista področja prava: ustavno pravo, upravno pravo, mednarodno pravo, kazensko pravo, postopkovno pravo, civilno pravo, gospodarsko pravo in delovno pravo (David in Grasmann 1998,157). Ta razdelitev se odraža tudi na nižji ravni, pri posameznih pravnih institutih in pojmih. Obenem pa v anglo-ameriškem pravu obstajajo koncepti, ki jih kontinentalno pravo ne pozna, kot npr. consideration $\mathrm{v}$ pogodbenem pravu. Kontinentalno pravo ima prav tako edinstvene pravne institute, kakršni so npr. kavza, zloraba pravice idr. Germanska pravna družina poleg tega pozna še pojem pravnega posla, izjavo volje ipd. Področje obligacijskega prava, ki je bilo razvito na osnovi elementov rimskega prava in je temeljnega pomena za kontinentalno pravo, nima ustreznice v anglo-ameriškem sistemu. Podobno pravo pravičnosti (equity) nima vzporednega področja v kontinentalnem pravu.

Kljub vsem tem razlikam pa ta dva sistema nista povsem nekompatibilna. Razlike sicer obstajajo, zaradi njih je prevajanje med temi sistemi sicer bolj zahtevno, ni pa nemogoče, saj končno oba sistema pripadata zahodni pravni tradiciji in političnim kulturam. Prihaja tudi do zbliževanja med njima zaradi medsebojnih vplivov ter prevzemanja konceptov in tradicij.

Upoštevajoč vse prepoznane razlike in sorodnosti je pri prevajanju pravnih besedil v slovenski jezik in iz njega računati z manj težavami, če bo prevod potekal med dvema pravnima sistemoma kontinentalne družine (npr. med slovenskim in nemškim ali obratno), kot v primeru, da bo prevod vključeval besedila s področja anglo-ameriškega prava. Pri zahtevnosti prevajalskih nalog pa je pomembno tudi, kakšno je razmerje med jezikoma, med katerima prevajamo. 


\subsection{Določanje razmerij med pravnimi jeziki, vključenimi v prevod}

Ko prevajamo med različnimi pravnimi sistemi, moramo oceniti stopnjo sorodnosti pravnih sistemov, obenem pa tudi upoštevati tipološko sorodnost jezikov, med katerimi poteka prevod. Če gre za nesorodne pravne sisteme, moramo računati s problemom pomanjkljive ekvivalence med pravnimi koncepti, v primerih, da prevajamo med sorodnimi jeziki, pa se moramo zavedati nevarnosti tveganja, da se pri prevodu pojavijo t. i. lažni prijatelji. De Groot s tem v zvezi opozarja, da je »/j/ezik prava ... močno sistemsko pogojen, to je jezik, ki je vezan na določen pravni sistem. Prevajalci pravne terminologije so se zato pri svojem delu primorani ukvarjati s primerjalnim pravom.« (1998, 21 - 22).

Sandrini $(1999,17)$ poudarja, da je, kar zadeva prevodljivost pravnih pojmov, pomembnejša sorodnost pravnih sistemov kot morebitna tipološka sorodnost jezikov.

Pomembno je tudi upoštevati, da je pri prevodu merodajen pravni sistem, $v$ katerega je vpet jezik, in ne morda splošna kultura, ki tvori podstat pravnega besedila. Pravne pojme je torej vselej potrebno obravnavati v luči ustreznega pravnega sistema. Weisflog (1987) s tem v zvezi omenja sistemsko režo (system gap), ki ločuje pravne sisteme in posledično pravne jezike. Večja kot je reža med sistemi, višja je stopnja prevajalske zahtevnosti in posledično nižja raven ekvivalence, ki jo lahko pričakujemo.

De Groot ugotavlja, da se glede na razmerja med jeziki in pravnimi sistemi pri prevajanju pravnih besedil vzpostavi ena od naslednjih možnih situacij (1992, 293-297):

- $\quad$ pravni sistemi in jeziki, ki sodelujejo v prevodu, so tesno povezani, kot v primeru Slovenije in Hrvaške, kar pomeni, da bo prevajanje sorazmerno enostavno;

- pravni sistemi so sorodni, jeziki pa niso, kot npr. pri prevajanju med nemškim pravnim sistemom in slovenskim pravom (v tem primeru prevajanje ne bo izjemno težavno);

- $\quad$ pravni sistemi so različni, jeziki pa so sorodni, v tem primeru bodo težave precejšnje, še posebej, ker sorodnost jezikov lahko privede do uporabe t. i. lažnih prijateljev, kar se dogaja pri prevajanju nemških pravnih besedil v nizozemščino in obratno;

- $\quad$ najtežja naloga je prevajanje med nesorodnimi pravnimi sistemi in prav tako nepovezanimi jeziki (ki tipološko ne sodijo v isto skupino), npr. prevajanje angleških besedil iz sistemov anglo-ameriške pravne družine v slovenščino.

V prevajalski praksi pa se izkaže, da de Grootova kategorizacija prevajalskih situacij ne prepoznava še dveh možnih scenarijev (Kocbek 2011, 154). Pri prvem gre za prevajanje znotraj (večjezičnega) mednarodnega ali pa nadnacionalnega pravnega sistema, npr. znotraj skupnosti OZN ali EU, kjer pa se pravne pojme, ki sodijo npr. v pravo EU, prevaja $\mathrm{z}$ uporabo obstoječe nacionalne terminologije. Takšni termini utegnejo biti obarvani s pomenom, ki se jim ga pripisuje znotraj izvirnega pravnega sistema, in če so tudi tolmačeni ob navezavi na ta sistem, obstaja tveganje napačnih interpretacij. 
Naslednji možni scenarij, povezan s potencialnimi prevajalskimi pastmi, je prevajanje med pravnimi sistemi, ki so relativno sorodni (npr. nemški in slovenski, ki oba sodita $\mathrm{v}$ sistem kontinentalnega prava), $\mathrm{v}$ katerih pa kot sredstvo komunikacije uporabimo tretji jezik, t. i. lingvo franko, ki se navezuje na pravni sistem, ki je dejansko irelevanten za dano komunikacijsko situacijo, kar se pogosto dogaja, ko kot lingva franka služi angleščina. V takšni situaciji mora biti načelo kulturne vpetosti uporabljeno selektivno, le na skladenjski, pragmatični in slogovni ravni besedila, na leksikalni ravni pa se moramo izogniti uporabi terminov in posledično konceptov pravnega sistema, na katerega se navezuje lingva franka, ki bi glede na pravne sisteme udeležencev v komunikaciji delovali kot tujki.

Težave, ki izhajajo iz neujemanja med sistemi anglo-ameriškega in kontinentalnega prava, so občutene tudi v EU, kjer je angleščina najpogosteje uporabljena lingva franka (Kjaer 1999, 72) in se uporablja za opisovanje pojmov evropskega prava ali nacionalnih pravnih sistemov držav članic, ki sodijo v kontinentalno pravno družino, pri čemer so uporabljeni termini pogosto obarvani s pomenom, ki ga imajo znotraj anglo-ameriške pravne družine.

Potem ko bo prepoznal enega od zgoraj opisanih scenarijev, bo prevajalec znal oceniti, kje tičijo morebitne prevajalske pasti zaradi pomanjkanja ekvivalence kot posledice nesorodnosti pravnih sistemov. Obenem se bo znal izogniti rabi lažnih prijateljev, kakršen je npr. prevod funkcije prokurista v nemških in slovenskih gospodarskih družbah z angleškim terminom procurator, ki bi lahko bil napačno razumljen kot »javni tožilec« (ki ga na Škotskem imenujejo procurator fiscal).

$\mathrm{S}$ tem, ko smo preučili razmerje med pravnimi sistemi in jeziki, ki so udeleženi $\mathrm{v}$ prevodu, smo osvetlili zunajbesedilno razsežnost pravnih besedil kot kulturemov, zato se v naslednjih korakih lahko posvetimo besedilnim razsežnostim oz. memetski strukturi.

\subsection{Analiza izvirnega besedila kot kulturema}

Na tej stopnji moramo določiti memetsko strukturo izvirnega besedila. Na makrostrukturni ravni zunajbesedilni dejavniki (pravni sistem in širša pravna kultura) določajo obseg besedila in tiste elemente, ki v določeni pravni kulturi veljajo kot obvezni ali standardni (v angleščini so imenovani boilerplate). Dober primerih takih elementov so preambula oz. uvodni del anglo-ameriških pogodb (Recital s t. i. Whereas clauses), pa klavzula z jamstvi in zagotovili (Representations and Warranties). Pri preučevanju te ravni besedila je ključno poznavanje ustreznih področij prava (v primeru pogodb pogodbenega prava v anglo-ameriškem pravem sistemu oz. prava obligacij v celinskoevropski pravni kulturi). Poleg tega moramo poznati tudi norme in konvencije, ki za pisanje pravnih besedil veljajo v različnih kulturah. Pravni sistem lahko v nekaterih primerih direktno vpliva na makrostrukturo besedila prek nadrejenih pravnih aktov. Za slovenske pogodbe npr. v 
vsakem primeru velja Obligacijski zakonik, pogosto pa za pogodbe veljajo tudi uzance ali neformalni pravni viri, kakršni so Splošni pogoji poslovanja; ti so pogosto celo izrecno omenjeni v besedilu, zato nekaterih določil v takem besedilu ni treba posebej navajati, ampak veljajo avtomatsko ob sklicevanju na nadrejeni akt. Tako so besedila kontinentalnih pogodb praviloma krajša kot primerljiva anglo-ameriška besedila. V študiji, v kateri primerjata nemške in ameriške gospodarske pogodbe, Hillova in King (2004) navajata, da besedila nemških pogodb običajno obsegajo polovico ali dve tretjini besedil primerljivih ameriških pogodb, sklenjenih v enake ali sorodne namene.

Ko v nadaljevanju preučujemo mikrostrukturo besedila, analiziramo posamezne besedilne ravni.

\subsubsection{Leksikalna raven}

Na leksikalni ravni je zlasti pomembno zaznati termine, ki dokumentirajo režo, ki ločuje pravne sisteme, zastopane v prevodu. Caova (2007, 60-63) poudarja, da se razlike med pravnimi sistemi kažejo predvsem na treh terminoloških področjih, t.j. terminih, ki označujejo različne vrste pravnih poklicev, različne vrste sodišč in sodnih struktur in pa specifična področja prava in pravne institute.

Na področju pravnih poklicev npr. pravni strokovnjak, ki mu država podeli licenco oz. pooblastilo za svetovanje strankam v pravnih zadevah in njihovo zastopanje na sodišču, ki ga v slovenščini imenujemo odvetnik, v nemščini pa Rechtsanwalt, nima neposredne prevodne ustreznice $\mathrm{v}$ anglo-ameriškem pravnem sistemu. V ZDA so odvetniki običajno imenovani lawyer ali attorney (bolj formalno attorney-at-law) in lahko brez izjeme zastopajo stranke pred sodiščem, ki priznava njihov status. V Združenem kraljestvu, Kanadi, Avstraliji in nekaterih drugih državah, se kategorija lawyer deli na barrister (ki je pooblaščen za nastopanje na sodiščih višje stopnje) in solicitor (ki strankam v glavnem svetuje in sme nastopati samo na sodiščih nižje stopnje), medtem ko se v škotskem pravu zanje uporablja termin advocate. Podobni terminološki problemi se pojavljajo na področju terminologije, ki zadeva sodne uradnike in pa strukturo in hierarhijo sodišč. V anglo-ameriškem pravosodju se uporabljata dva izraza za označevanje sodišč: splošni izraz court in ožji termin tribunal, ki se nanaša na organe in telesa, ki opravljajo upravne ali parasodne funkcije $z$ omejeno ali posebno jurisdikcijo, medtem ko se v nemščini in slovenščini uporablja en sam termin, in sicer Gericht oz. sodišče.

Pri analizi izvirnih besedil, sestavljenih v angleščini, naletimo na zanimivo terminološko posebnost, na t. i. besedne pare (npr. bind and obligate, deem and consider) in besedne nize (npr. all taxes, levies, duties, imposts, charges and withholdings of any nature whatsoever). Ti besedni pari predstavljajo poseben primer sinonimije ali polsinonimije, izvirajo namreč iz starih anglosaksonskih obrednih pravnih obrazcev, sestavljenih iz dveh besed s povezanim pomenom, ki so bile pogosto aliterirane. V srednjeveški angleščini se je tako podvajanje nadaljevalo in tako so se v pare združevale 
angleška beseda s svojo francosko ustreznico (npr. acknowledge and confess). Ta tradicija je bila kasneje razširjena $\mathrm{v}$ oblikovanje besednih nizov, ki so pravzaprav nizi polsinonimov ali besed s sorodnim pomenom. Značilno za te vrste besednih nizov je, da poskušajo biti čim izčrpnejši ( $v$ angleščini je ta lastnost opisana kot all-inclusiveness), obenem pa zaradi tveganja, da kljub vsemu ne zajamejo vsega želenega, pogosto vsebujejo formulacijo including, but not limited to ali including, without limitation (»vključno z vsem navedenim, vendar ne omejeno na vse navedeno« ali »vključno z, a brez omejitev«).

Besedni pari in nizi lahko predstavljajo vir prevajalskih problemov pri prevajanju v ciljni jezik, v katerem ni na razpolago tolikšnega števila sopomenk, zato jih je pogosto potrebno prevajati s krajšimi strukturami.

Nadaljnji terminološki izziv za prevajalca je celotno področje metaforično generiranega pravnega izrazja. Nekateri metaforično generirani termini so univerzalni in jih je mogoče najti v besedišču različnih pravnih kultur (npr. small print / Kleindruck / drobni tisk; third parties/ Drittel tretje stranke; force majeure / höhere Gewalt / višja sila), čeprav kljub navidezni ekvivalenci nimajo vselej povsem enakega pomena (prim. Cao 2007, 57-58).

Kljub temu, da bi v pravnem jeziku zaradi splošnega prizadevanja za enoznačnost in nedvoumnost pravnega izražanja pričakovali manj metaforično nastalih izrazov, različni pravni jeziki uporabljajo vrsto pravnih metafor, kot so npr. lifting/piercing the corporate veil (pri družbah z omejeno odgovornostjo razveljaviti razmejitev med odgovornostjo družbe in osebno odgovornostjo družbenika), yellow dog contract (v izvirnem pomenu pogodba sklenjena med delodajalcem in delavcem, s katero se delavec odpoveduje članstvu v sindikatu), Faustpfandrecht (ročna zastavna pravica) ipd.

Pri prevajanju besedil iz pravnih sistemov t. i. zahodne tradicije (torej tako angloameriških kot tudi kontinentalnih), se prevajalci pogosto soočajo $\mathrm{z}$ besedami in frazami latinskega izvora ali v latinskem jeziku. Pri tem je treba upoštevati, da so nekateri od teh izrazov univerzalni in se kot taki uporabljajo $\mathrm{v}$ številnih pravnih jezikih s pretežno enakim pomenom (npr. bona fides, pro bono, ex officio) in lahko zato tudi v prevedenem besedilu ostanejo v izvirni obliki, medtem ko so drugi strogo vezani na določen pravni sistem, kar velja za mnoge latinske izraze, ki so v rabi v pravni angleščini (npr. affidavit izjava pod prisego; amicus curiae - oseba, ki ni stranka v postopku v ožjem smislu, pa jo sodišče povabi, da kot svetovalec ali izvedenec pomaga razjasniti zapleten primer; stare decisis - doktrina precedensa, itd.), in jih je torej potrebno prevesti.

\subsubsection{Skladenjska raven}

Po leksikalni ravni je smiselno analizirati skladenjsko raven izvirnega kulturema. V angleških in nemških besedilih se na tej ravni srečujemo z izjemno razširjeno rabo trpnika. V slovenskh pravnih besedilih je trpnik dopusten in smiseln vselej, kadar je vršilec 
samoumeven ali izvrševalec nečesa, kar določa zakon ali predpis. Danes je v slovenskih pravnih besedilih trpnik skupaj z brezosebnim izražanjem konstitutivna prvina pravnih in uradovalnih besedil, ker daje tem besedilom ton uradnosti (Kalin Golob 2003, 32-33). Nemški jezik poleg tega uporablja številne neosebne glagolske oblike, kopiči atributivne pridevnike, pravna angleščina pa uporablja večkratne negacije in številne predložne zveze (Cao 2007, 21).

Na tej ravni je treba tudi ugotoviti prevladujoče stavčne strukture, kot so npr. značilni pogojni odvisniki v angleščini, ki se začenjajo s provided that.

\subsubsection{Slogovna raven}

Na slogovni ravni bomo ugotavljali stopnjo formalnosti in jezikovna sredstva za doseganje učinka objektivnosti, uradnosti besedila, formalen in brezoseben slog, ki ga označuje tudi raba dolgih, priredno in podredno sestavljenih povedi. Pri analizi sloga pravnega besedila je smiselno upoštevati Tetleyjeve ugotovitve $(2000,703)$ glede sloga pravnih besedil, in sicer, da je slog kontinentalnih pravnih besedil strnjen in zgoščen ter odraža deduktivni način razmišljanja, slog anglo-ameriških pa natančen in izčrpen in vezan na induktivni način razmišljanja.

\subsubsection{Pragmatična raven}

Na pragmatični ravni je v pravnih besedilih praviloma mogoče zaznati nekatere univerzalne lastnosti, kot je npr. uporaba specifičnih jezikovnih struktur za uresničevanje določenih govornih dejanj, kot so vzpostavljanje obveznosti, podeljevanje pravic, dajanje dovoljenja, izražanje prepovedi, izrekanje sodb ipd. Zakonska besedila, pogodbe, oporoke so pravzprav najboljši primeri performativne rabe jezika, zato v njih naletimo na nabor različnih jezikovnih sredstev, ki so se v določeni pravni kulturi ustalila za izražanje ključnih pravnih razmerij, kot so npr. naklonski glagoli shall in may v angleščini ter performativni glagoli in glagolske zveze kot so »izjaviti, razsoditi, proglasiti, zavezati se, prevzeti obveznosti, podeliti pravico itd.« in njihove ustreznice v drugih jezikih. Ko si bo torej prevajalec ustvaril jasno podobo kulturema pogodbenega besedila v izvirnem jeziku in izvirni pravni kulturi, jo bo lahko primerjal s kulturemom, ki za pogodbena besedila obstaja v ciljni kulturi.

\subsection{Določanje kulturema besedila v ciljni kulturi}

Na podlagi poznavanja ciljne pravne kulture in načinov, kako norme in konvencije te kulture oblikujejo besedilne vrste sorodne izvirnemu besedilu, prevajalec oblikuje hipotetično podobo oz. ogrodje ciljnega besedila na podoben način, kot je določil strukturo kulturema izvirnega besedila, torej določi področje prava, kamor sodi, in pa vse 
razsežnosti kulturema na makro in mikro ravni. S tem, ko bo povezal svoje znanje o ciljnem in izvirnem pravnem jeziku ter pripadajočih pravnih sistemih, bo sposoben napovedati potencialne prevajalske pasti, ki izhajajo iz razkoraka med pravnimi sistemi in razlik med pravnimi jeziki.

\subsection{Primerjava izvirnega in ciljnega kulturema}

Po primerjavi kulturema izvirnega besedila s hipotetičnim kulturemom ciljnega besedila bomo določili prekrivanja in odstopanja med njima. V primerih, ko na leksikalni ravni zaradi nesorodnosti pravnih sistemov ni mogoče najti ekvivalentnih prevodnih rešitev za določene pojme oz. termine, bomo uporabili eno od naslednjih rešitev, ki jih predlaga de Groot $(1998,25)$, in sicer ohranimo termin v izvirnem jeziku v izvirni ali transkribirani različici (ter po potrebi dodamo razlago ali komentar $\mathrm{v}$ opombi), izvirni termin parafraziramo ali ustvarimo neologizem, pri čemer je smiselno uporabiti latinske ali starogrške korene in (po potrebi) dodati razlago $\mathrm{v}$ opombi.

Mattila opozarja na še eno pogosto uporabljeno rešitev, in sicer tvorbo kalka oz. prevzete besede (2006, 119-121).

$\mathrm{Na}$ ostalih ravneh besedila se bo prevajalec glede na vsakokratni skopos odločil, kateri memi bodo neposredno preneseni iz memetske strukture izvirnega kulturema. To so lahko memi, ki so se pri primerjalni analizi besedil izkazali kot univerzalni memi (npr. raba strokovnega pravnega izrazja, uraden slog besedila), pa tudi takšni, ki so sicer prototipični za izvirno pravno kulturo in morda niso običajni za ciljno pravno kulturo, a jih je treba ohraniti zaradi upoštevanja skoposa, npr. zato, ker tudi za ciljno besedilo velja kot merodajen izvirni pravni sistem in je potrebno spoštovati besedilne norme in konvencije izvirne kulture, ali pa zato, ker bo ciljno besedilo služilo prejemnikom v ciljni kulturi kot podlaga za preučevanje pravne ureditve in jezika $v$ izvirnem pravnem sistemu. Nekatere meme bomo morali spremeniti in prilagoditi ciljni pravni kulturi (zlasti v primeru, ko izvirno besedilo služi kot podlaga za ciljno besedilo, ki mora biti prilagojeno normam in konvencijam ciljnega pravnega sistema). Te spremembe lahko posegajo bolj ali manj globoko $\mathrm{v}$ besedilo in predvidevajo spremembe v površinski strukturi besedila, kot je zamenjava trpnika $\mathrm{v}$ angleških in nemških besedilih z drugimi glagolskimi oblikami $\mathrm{v}$ slovenščini, do konceptualnih sprememb, kakršna je zamenjava pojma consideration $\mathrm{s}$ sorodnim, vendar nikakor ne enakovrednim konceptom pogodbene cene v pogodbah celinskoevropskega prava. V nekaterih primerih bodo ustrezno skoposu nekateri memi morali biti opuščeni, kot npr. vsebinski elementi anglo-ameriških pogodb, ki niso običajni v kontinentalnih besedilih, če se prevod povsem prilagaja ciljnemu pravnemu okolju. Po drugi plati bo, da bi se prilagodili memetski strukturi besedil v ciljni kulturi, včasih potrebno dodati nove (obvezne ali standardne) vsebinske elemente ali pa spremeniti vrstni red vsebinskih elementov. 


\subsection{Dokončno oblikovanje ciljnega besedila}

$\mathrm{V}$ tej fazi se prevajalec posveti oblikovanju končne podobe ciljnega besedila. Pri tem upošteva ugotovitve predhodnih faz in posnema tiste meme obeh kulturemov, za katere so predhodne faze pokazale, da so smiselni glede na skopos. Pomembna smernica v tej fazi prevajalskega ravnanja je spoznanje, da glede na skopos v ciljnem besedilu lahko sobivajo memi različnih kultur (npr. vsebinski elementi in leksikalni memi merodajnega izvirnega pravnega sistema, skupaj z memi ciljne kulture na slogovni, skladenjski in pragmatični ravni).

Pri realizacijah preostalih besedilnih ravni je pri oblikovanju končne podobe besedila smiselno upoštevati ugotovitve analize kulturemov v izvirni in ciljni kulturi in posnemati meme, ki so prototipični za posamezne pravne kulture. Še zlasti pomembno je, da pri ubesediljenju ključnih pravnih razmerij, vzpostavljanju obveznosti, podeljevanju in uresničevanju pravic, uporabimo jezikovna sredstva, ki so se zaradi pogostosti in razširjenosti izkazala kot prototipična za posamezne pravne jezike. Upoštevati moramo npr., da ima angleški prihodnjik s shall kot absolutno najpogosteje uporabljeno jezikovno sredstvo za izražanje obveznosti v anglo-ameriških besedilih močnejši pragmatični naboj kot nemški ali slovenski prihodnjik in ga je zato smiselno nadomestiti z leksikalnimi jezikovnimi sredstvi, ki so prototipična za nemški in slovenski pravni jezik, kakršna so npr. glagoli »zavezati se«, »obvezati se« ali sich verpflichten in druge pomensko sorodne strukture.

\subsection{Preverjanje pravne varnosti ciljnega besedila in utemeljenosti prevajalskih odločitev}

Glede na performativno naravo pravnega jezika in dejstvo, da imajo pravna besedila neposreden učinek na resničnost, npr. pri vzpostavljanju obveznosti in pravic, se mora prevajalec pravnih besedil zavedati morebitnih posledic napačnega prevoda in prevzeti odgovornost za posledice svojega dela. Sandrini $(1999,39)$ s tem v zvezi navaja dve smernici. Prva prevajalcu narekuje, da mora poskrbeti za pravno varnost ciljnega besedila. $\mathrm{V}$ ta namen mora temeljito preveriti pravno podlago besedila in se, posebno če se mu pojavljajo dvomi, posvetovati s pravnim strokovnjakom. Druga smernica pa narekuje transparentnost prevajalskih odločitev, torej predpisuje, da mora prevajalec znati zagovarjati in utemeljevati svoje prevajalske odločitve, za kar nujno potrebuje interdisciplinarno znanje, ki obsega poznavanje pravnih sistemov, ki so udeleženi v prevodu, pripadajočih pravnih jezikov in pa kulturemov pravnih besedil, kakršni obstajajo v zadevnih pravnih kulturah. 


\section{3} ZAKLJUČEK

Namen predstavljenega prevajalskega modela je bil zasnovati sistematičen postopek prevajanja, ki naj zajame in upošteva vse razsežnosti pravnih besedil. Obenem želi tudi opozoriti na dejstvo, da pri prevajanju pravnih besedil zahtevnost prevajalskega dela ni omejena le na reševanje problemov na terminološki in širši leksikalni ravni besedila, temveč zadeva vse ravni, ki besedilo določajo kot kulturem. Čeprav model priznava in upošteva ključno vlogo leksikalne ravni pravnih besedil, želi obenem razširiti zorni kot in poleg terminološke postopoma zajeti vse ostale ravni besedila, vse dokler ni upoštevana tudi zunajbesedilna razsežnost, $\mathrm{v}$ kateri je besedilo vpeto $\mathrm{v}$ vsakokratni pravni sistem in širšo pravno kulturo ter služi določenemu sporazumevalnemu namenu. Model tudi opozarja, da deluje terminologija oz. leksikalna raven v pravnem besedilu kot konica ledene gore, ki opozarja na njegovo kompleksno strukturiranost in interdisciplinarnost. Da bi mogli v celoti upoštevati kompleksnost pravnega besedila in jo ustrezno prenesti v drugo kulturo in drug jezik, ga moramo obravnavati v luči dognanj prevodoslovja in primerjalnega prava. Model je nastal na podlagi dolgoletnih prevajalskih izkušenj avtorice in njenega raziskovalnega dela na področju prevodoslovja in pravnega jezikoslovja. Zamišljen je kot dinamično orodje, zato je od prve zasnove doživel že vrsto sprememb in prilagoditev, razumeti ga je predvsem kot zbirko smernic, ki naj dvigajo zavest o občutljivih plateh pravnega prevajanja in pripomorejo $\mathrm{k}$ bolj funkcionalnim in $\mathrm{s}$ tem kvalitetnejšim prevodom.

\section{VIRI}

BUSSE, D. (2000) Textsorten des Bereichs Rechtswesen und Justiz. K. Brinker, G. Antos, W. Heinemann, in S.F. Sager (ur.), Text- und Gesprächslinguistik. Ein internationales Handbuch zeitgenössischer Forschung. Berlin in New York: de Gruyter, 658-675.

CAO, D. (2007) Translating Law. Clevedon: Multilingual Matters.

CHESTERMAN, A. (1997) Memes of Translation. Amsterdam in Philadelphia: John Benjamins.

CRUZ DE, P. (1999) Comparative Law in a Changing World. London: Cavendish Publishing.

DAVID, R./D. GRASMANN (1998) Uvod v velike sodobne pravne sisteme. Prevedel V. Lamut. Ljubljana: Cankarjeva založba.

GROOT DE, G.-R. (1992) Recht, Rechtssprache und Rechtssystem. Betrachtungen über die Problematik der Übersetzung juristischer Texte. Office des publications officielles des Communautés européennes: Terminologie et traduction. Bruselj in Luksemburg: Commission des Communautés Européennes. 279-316. 
GROOT DE, G.-R. (1998) Language and Law. Netherlands reports to the Fifteenth International Congress of Comparative Law. Antwerp in Groningen: Intersentia, 21-32.

HILL, C. A./Ch. KING (2004) How Do German Contracts Do As Much with Fewer Words? Chicago-Kent Law Review 79, 889-926.

KALIN GOLOB, M. (2003) Jezikovne reže 2. Ljubljana: GV Revije.

KOCBEK, A. (2011) Prevajanje pravnih besedil: pasti in strategije v prevodih pogodb. Koper: Fakulteta za management.

KJÆR, A. L. (1999) Überlegungen zum Verhältnis von Sprache und Recht bei der Übersetzung von Rechtstexten der Europäischen Union. P. Sandrini (ur.), Übersetzen von Rechtstexten: Fachkommunikation im Spannungsfeld zwischen Rechtsordnung und Sprache. Tübingen: Narr, 63-79.

MATTILA, H. S. (2006) Comparative Legal Linguistics. Aldershot: Ashgate.

NORD, C. (1997) Translating as a purposeful activity: Functionalist approaches explained. Manchester: St. Jerome.

OKSAAR, E. (1988) Kulturemtheorie: Ein Beitrag zur Sprachverwendungsforschung. Hamburg:. Joachim Jungius Gesellschaft der Wissenschaften.

REIß, K./ H. J. VERMEER (1984) Grundlegung einer allgemeinen Translationstheorie. Tübingen: Niemeyer.

SAGER, J.C. (1990) A Practical Course in Terminology Processing. Amsterdam in Philadelphia: John Benjamins.

SAGER, J. C. (1997) Text Types and Translation. A Trosborg (ur.), Text Typology and Translation, Amsterdam in Philadelphia: John Benjamins, 25-41.

SANDRINI, P. (1999) Translation zwischen Kultur und Kommunikation: Der Sonderfall Recht. P. Sandrini (ur.), Übersetzen von Rechtstexten: Fachkommunikation im Spannungsfeld zwischen Rechtsordnung und Sprache. Tübingen: Narr, 9-43.

SNELL-HORNBY, M. (1995) Translation Studies: An Integrated Approach: Revised Edition. Amsterdam in Philadelphia: John Benjamins.

TETLEY, W. (2000) Mixed Jurisdictions: Common Law vs. Civil Law (Codified and Uncodified). Louisiana Law Review 60: 677-738.

VERMEER, H. J. (1983) Translation Theory and Linguistics. R. Roinila, R. Orfanos, in S. Tirkkonen-Condit (ur.), Näkökohtia käänämisen tutkimuksesta. Joensuu: University of Joensuu, 1-10.

WEISFLOG, W. E. (1987) Problems of Legal Translation. Swiss Reports presented at the XIIth International Congress of Comparative Law. Zürich: Schulthess, 179-218. ZWEIGERT, K./H. KÖTZ (1998) An Introduction to Comparative Law, 3.izd. Prevedel T. Weir. Oxford in New York. Clarendon Press. 


\section{POVZETEK}

Prispevek predstavlja avtoričin model za prevajanje pravnih besedil, v katerem so funkcionalistični prevodoslovni pristopi združeni z dognanji primerjalnega prava in pravnega jezikoslovja. Sestavljen je iz desetih smernic, ki prevajalca vodijo od določanja funkcije ciljnega besedila (skoposa) in izbire ustrezne vrste prevoda, prek primerjave pravnih sistemov udeleženih v prevodu ter analize memetske strukture izvirnega besedila in sorodnih besedil v ciljni kulturi do oblikovanja ciljnega besedila kot kulturema in zagotavljanja njegove pravne varnosti.

Ključne besede: kulturem, memetska struktura, pravno prevajanje, skopos, primerjalno pravo

\section{ABSTRACT}

\section{Ten Guidelines for Translating Legal Texts}

The paper proposes a targeted model for translating legal texts, developed by the author by combining translation science (i.e. functionalist approaches) with the findings of comparative law and legal linguistics. It consists of ten guidelines directing the translator from defining the intended function of the target text and selecting the corresponding translation type, through comparing the legal systems involved in the translation and analysing the memetic structure of the source text and parallel texts in the target culture to designing the target text as a cultureme and ensuring its legal security.

Key words: cultureme, memetic structure, legal translation, skopos, comparative law. 